\title{
Vitamin D Deficiency is Associated with Overweight and/or Obesity among Schoolchildren in Central Ethiopia: A Cross-Sectional Study
}

\author{
Tolassa Wakayo ${ }^{1, *}$, Susan J. Whiting ${ }^{2}$ and Tefera Belachew ${ }^{1}$ \\ 1 College of Health Sciences, Jimma University, Jimma, Ethiopia; teferabelachew@gmail.com \\ 2 College of Pharmacy and Nutrition, University of Saskatchewan, Saskatoon, SK S7N 2Z4, Canada; \\ susan.whiting@usask.ca \\ * Correspondence: wakayotolassa@yahoo.com; Tel.: +251911909644
}

Received: 21 December 2015; Accepted: 22 March 2016; Published: 1 April 2016

\begin{abstract}
Childhood and adolescent obesity is an international public health problem leading to an increased risk of adulthood obesity, mortality and morbidity. Its prevalence is increasing in low-income populations, and we hypothesized it may be associated with vitamin D deficiency. Low vitamin D status is a worldwide public health issue including in Ethiopia; however, no one has examined overweight/obesity in Ethiopian schoolchildren with regard to vitamin D status. The Analyses of a data set from a school-based cross-sectional study conducted in Adama Town $(n=89)$ and in rural Adama Woreda $(n=85)$ was carried out to determine vitamin D deficiency and its association with overweight and/or obesity. Data on a total of 174 schoolchildren aged 11-18 years was used for these analyses. The overall prevalence of overweight and/or obesity was $10.3 \%$, with $8.5 \%$ overweight and $2.3 \%$ obese; the prevalence of underweight was $19 \%$. In the multivariable logistic regression model, vitamin D deficiency, being in the higher age group, female sex and urban residence of students, their mothers' occupation of being employed and their households' high and middle socioeconomic status were significantly associated with overweight and/or obesity. We concluded that vitamin D deficiency is an independent predictor significantly associated with overweight and/or obesity among schoolchildren from rural and urban settings in Ethiopia. The results imply the need for behavior change communications on the importance of exposure to sunlight to produce adequate vitamin $\mathrm{D}$ to curb this emerging health problem of overweight/obesity following economic growth and globalization in Ethiopia. As this study only highlighted the association, prospective studies and randomized controlled trials are required to establish causality.
\end{abstract}

Keywords: vitamin D deficiency; overweight/obesity; schoolchildren; Ethiopia

\section{Introduction}

Childhood and adolescence obesity is an international public health problem leading to an increased risk of adult obesity and associated mortality and morbidity [1]. Although it has been previously associated primarily with high-income countries, overweight and obesity are now becoming prevalent in populations from low- and middle-income countries due to the effect of globalization [2]. While the prevalence of obesity may be stabilizing in developed countries [3-5], it is now increasing in developing countries [6-9]. This change is currently high in Middle East and Asian countries [10,11], but Africa is also experiencing a shift from underweight to overweight. In Africa, there are socioeconomic, nutritional and physical activity transitions taking place, which these lead to increases in the use of energy-saving devices, the availability of cheap high-calorie dense foods and limited participation in physical activity at home and at school [12-17]. The trend of rising overweight/obesity prevalence has been observed in Ethiopia, particularly in women [18] and children [19]. The fact 
that Ethiopia is one of the countries in East Africa undergoing rapid socioeconomic growth in the recent years is assumed to be a risk factor for this rising trend in overweight and/or obesity given that overweight and/or obesity is directly related to socioeconomic status in developing economies [20].

Vitamin D deficiency has also been identified as a worldwide public health issue that is associated with an increase in the prevalence of related-chronic diseases. Vitamin D is produced from cholesterol in the skin upon exposure to sunlight. It can also be obtained from foods and supplements. Apart from being needed for bone health and calcium homeostasis, vitamin D has extra-skeletal functions [21]. In vitro and animal studies over the past decades have extended the role of vitamin $\mathrm{D}$ to other tissues, including the pancreas [22], thus implicating it for glucose and fat homeostasis and hence, providing a mechanism for how vitamin D might contribute to overweight and/or obesity [22-24]. We have previously reported that vitamin D deficiency is prevalent among Ethiopian schoolchildren both in urban and rural settings accounting for $61.8 \%$ and $21.2 \%$, respectively [25]. Other studies conducted on pregnant women and women of reproductive age group also showed that vitamin D deficiency is prevalent in Ethiopia [26-28]. There have been a few studies examining the prevalence of overweight and/or obesity and its associated risk factors among schoolchildren in different parts of Ethiopia [29-32]; however, none looked at whether vitamin D deficiency was associated with overweight and/or obesity among schoolchildren. In these analyses, we set out to demonstrate whether vitamin D deficiency may significantly be associated with overweight and/or obesity among schoolchildren aged 11-18 years in Ethiopia.

\section{Methods and Materials}

\subsection{Study Design, Participants and Setup}

The analyses of data set from school based cross-sectional study conducted in Adama Town $(n=89)$ and in Rural Adama Woreda (district) $(n=85)$ from 20 May-22 June 2013 was carried out to determine vitamin D deficiency and its association with overweight/obesity among Ethiopian schoolchildren. Data on a total of 174 schoolchildren aged 11-18 years were used for these analyses. Sample size was calculated using formula for estimating two population proportions using a power of $80 \%$. Multi-stage stratified random sampling procedures were used to select study subjects from each study setting. Further details including sampling procedure, inclusion/exclusion criteria, protocol approval and ethics statements are published elsewhere [25].

\subsection{Analysis of $25-H y d r o x y v i t a m i n ~ D$}

After obtaining signed informed written consent from the parents/guardians and verbal assent from the children, each child had a finger pricked by trained health workers, from which free-flowing blood drops were collected on blood spot cards as per ZRT laboratory instructions [33]. At least two such usable (non-overlapping) drops were collected per subject. After air drying for at least $30 \mathrm{~min}$, flaps were closed and placed in the sealed Ziploc bags with desiccant and moisture indicators, and taken to Oromia Public Health Research, Capacity Building and Quality Assurance Laboratory by principal investigator for storage at $-80^{\circ} \mathrm{C}$. Samples were then sent for analysis to ZRT laboratory (Beaverton, OR, USA), within 4 days. Circulating serum 25(OH)D was analyzed from dried blood spots, using a standard liquid chromatography/tandem mass spectrometry (LC-MS/MS) assay having intra-assay and inter-assay coefficients of variation (CVs) of $8.1 \%$ to $9.2 \%$ and $12 \%$ to $13 \%$, respectively. The ZRT Laboratory participates in DEQAS (the Vitamin D Quality Assessment Scheme), which provides control samples to ensure assay accuracy and the blood spot $25(\mathrm{OH}) \mathrm{D}$ determination is deemed equivalent to serum as stability of $25(\mathrm{OH}) \mathrm{D}$ in serum or plasma is high [33]. A cut-off for deficiency of $<50 \mathrm{nmol} / \mathrm{L}$ was based on consideration of the Endocrine Society Clinical Practice for Evaluation, Treatment, and Prevention of Vitamin D Deficiency [34]. 


\subsection{Anthropometric Data}

Body weight, height, and triceps skinfold thickness were measured using a precision digital scale (HD-318; TANITA), portable stadiometer, and Holtain skinfold caliper, respectively. Children removed their shoes and jackets for height and weight measurements. Body Mass Index (BMI) was calculated as weight in kilogram divided by height in squared meter $\left(\mathrm{kg} / \mathrm{m}^{2}\right)$. The triceps skinfold thickness (TSF) was measured at the upper arm mid-point mark between acromion process of shoulder blade and olecranon process of ulna on the posterior surface of the left upper arm. Weight, height and skinfold thickness were measured 3 times and the means were used for analyses. Data for BMI were compared to new 2007 WHO references for specific age and sex using Anthroplus software and data for TSF were compared to 1995 WHO references for specific age and sex [35] as there is no reference value for TSF from more recent WHO references. Every morning and prior to each measurement, the weight scale was calibrated with a standard weight and instruments were calibrated according to the manufacturer's recommendations.

\subsection{Socioeconomic Index}

Socioeconomic index was categorized as follows: first all study participants were asked about the ownership of fixed assets by their respective households with a score " 1 " given to those who own the asset and score of " 0 " given to those who did not own. Then, all items asked were assessed for internal consistency and showed to be reliable with a Cronbach's alpha value of 0.82 . Then, principal component analysis was used to generate wealth index from fixed assets, including ownership of household furniture, equipment, animals and other local indicators of wealth such as mills, generator, bicycle, motor cycle and beehive. Then wealth index was rank ordered into tertiles to give low, middle and high socioeconomic status.

\subsection{Statistical Analysis}

Data were checked for missing values and outliers, and analyzed using SPSS for window (SPSS Inc., version 16.1, Chicago, IL, USA). Normality of the continuous variables was checked visually using inspection of the skewness and kurtosis measures of their respective standard errors, histograms and Q-Q plots of residuals against the predicted values and box plots and using the Kolmogrov-Smirnov test. Logarithmic transformations were made as necessary for data that were not normally distributed. Mean values between groups were compared using independent sample $t$-test for normally distributed data and nonparametric tests (Mann-Whitney test and Kruskal-Wallis test) were used for data that were not normally distributed. Chi-square tests were used to compare categorical data between groups. TSF values of students were not normally distributed even after logarithmic transformations. Hence, TSF values were grouped into two (i.e., TSF-for-age $\geqslant 90$ th percentile as "overweight and /or obese" and $<90$ th percentile as "not overweight and/or obese") to allow entry into the logistic regression model. Then, to determine predictors associated with overweight and/or obesity, we first carried out bivariate analyses to identify candidate variables for the multivariable logistic regression model. Second, to identify the significant independent predictors associated with overweight and/or obesity at an alpha level of 0.05 , variables that had $p<0.25$ in the bivariate analyses were entered into multivariable logistic regression model using backward elimination stepwise likelihood ratio method. All tests were two-sided and $p<0.05$ was considered statistically significant. The results were reported as Odds Ratio (OR) and 95\% Confidence Interval (CI).

\section{Results}

A total of 174 study participants from the schools in two settings, in Adama Town (89 (51.1\%)) and rural kebeles (wards) of Adama Woreda (85 (48.9\%)) participated in the study (response rate 98\%). The median (range) age of the students was 15 (11-18) years. Higher proportions of students were females than males (56.9\% vs. $43.1 \%)$, and in the age group $15-18$ years $(55.7 \%)$; most $(79.9 \%)$ of them 
were Christian by religion. The majority of mothers and fathers had attended a formal education $(69 \%$ and $55.4 \%$, respectively). Only a small proportion of mothers and fathers were employed. Almost equal proportions of the study subjects were from households in low (34.5\%) and high (35.1\%) socioeconomic status (Table 1).

Table 1. Characteristics of schoolchildren in Central Ethiopia.

\begin{tabular}{|c|c|c|}
\hline \multicolumn{2}{|c|}{ Characteristics $(n=174)$} & \multirow{2}{*}{$\begin{array}{c}\text { Frequency (\%) } \\
75(43.1)\end{array}$} \\
\hline \multirow{2}{*}{ Sex } & Male & \\
\hline & Female & $99(56.9)$ \\
\hline \multirow{2}{*}{ Age groups } & $11-14$ & $77(44.3)$ \\
\hline & $15-18$ & $97(55.7)$ \\
\hline \multirow[t]{2}{*}{ Residence } & Urban & $89(51.1)$ \\
\hline & Rural & $85(48.9)$ \\
\hline \multirow{2}{*}{ Religion } & Christians & $139(79.9)$ \\
\hline & Muslims & $35(20.1)$ \\
\hline \multirow{2}{*}{ Educational status (Father) } & No formal education & $54(31)$ \\
\hline & Formal education & $120(69)$ \\
\hline \multirow{2}{*}{ Educational status (Mother) } & No formal education & $77(44.3)$ \\
\hline & Formal education & $97(55.7)$ \\
\hline \multirow{2}{*}{ Occupation (Father) } & Employed & $50(28.7)$ \\
\hline & Self employed/Unemployed & $124(71.3)$ \\
\hline \multirow{2}{*}{ Occupation (Mother) } & Employed & $26(14.9)$ \\
\hline & Self employed/Unemployed & $148(85.1)$ \\
\hline \multirow{3}{*}{ Socioeconomic status } & Low & $60(34.5)$ \\
\hline & Medium & $53(30.5)$ \\
\hline & High & $61(35.1)$ \\
\hline \multirow{3}{*}{ WHO BMI-for-age percentile } & Underweight & $33(19)$ \\
\hline & Normal & $129(74.1)$ \\
\hline & Overweight and/or obese & $12(6.9)$ \\
\hline \multirow[t]{2}{*}{ WHO TSF-for-age percentile } & Overweight and/or obese & $18(10.3)$ \\
\hline & Overweight and/or obese & $156(89.7)$ \\
\hline \multirow[t]{3}{*}{ Serum $25(\mathrm{OH}) \mathrm{D}$} & Deficient $(<50 \mathrm{nmol} / \mathrm{L})$ & $73(42)$ \\
\hline & Insufficient (50-74.9 nmol/L) & $86(49.4)$ \\
\hline & Sufficient $(\geqslant 75 \mathrm{nmol} / \mathrm{L})$ & $15(8.6)$ \\
\hline Mean BMI & $17.9 \pm 2.9 \mathrm{~kg} / \mathrm{m}^{2}$ & \\
\hline Median TSF & $12(5.2-31.2) \mathrm{mm}$ & \\
\hline Mean serum 25(OH)D & $54.5 \pm 15.8 \mathrm{nmol} / \mathrm{L}$ & \\
\hline \multirow{2}{*}{ Difference in mean BMI } & Deficient vitamin D status ${ }^{\mathrm{e}}$ & $18.6 \pm 3.2 \quad p=0.003$ \\
\hline & Normal vitamin D status & $17.3 \pm 2.5$ \\
\hline
\end{tabular}

e Definition of vitamin D status (vitamin D deficiency = serum $25(\mathrm{OH}) \mathrm{D}<50 \mathrm{nmol} / \mathrm{L}$ and normal $=$ serum $25(\mathrm{OH}) \mathrm{D} \geqslant 50 \mathrm{nmol} / \mathrm{L})$.

The overall prevalence of overweight and/or obesity was $10.3 \%$, with $8.5 \%$ overweight and $2.3 \%$ obese using TSF-for-age. The prevalence became less (6.9\%) using BMI-for-age. The prevalence of underweight was 19\% using BMI. The mean and median BMI and TSF of the students were $17.9 \pm 2.9 \mathrm{~kg} / \mathrm{m}^{2}$ and $12(5.2-31.2 \mathrm{~mm})$, respectively. Average serum $25(\mathrm{OH}) \mathrm{D}$ for the group was $54.5 \pm 15.8 \mathrm{nmol} / \mathrm{L}$. Nearly half $(42 \%)$ of the study subjects were vitamin D deficient (serum $25(\mathrm{OH}) \mathrm{D}<50 \mathrm{nmol} / \mathrm{L}$ ) while $49.4 \%$ were vitamin D insufficient (serum 25(OH)D 50-74.9 nmol/L). Only $8.6 \%$ of the study subjects were vitamin $\mathrm{D}$ sufficient (serum $25(\mathrm{OH}) \mathrm{D} \geqslant 75 \mathrm{nmol} / \mathrm{L}$ ). The deficiency is more prevalent in girls and urban students compared to their respective counterparts ( $51.5 \%$ vs. $29.3 \%$ and $61.8 \%$ vs. $21.2 \%$, respectively). Students in the higher (15-18 years) age group 
had higher prevalence of vitamin D deficiency (49.5\%) compared to those in lower (11-14 years) age group (32.5\%). Vitamin D deficient children had statistically significantly ( $p=0.003$ ) higher BMI than children with normal vitamin D status. Serum $25(\mathrm{OH}) \mathrm{D}$ was inversely correlated with both BMI and TSF values $(r=-0.233 ; p=0.002$ and Spearman's rho $=-0.395 ; p<0.001$, respectively).

A Mann-Whitney $U$ test showed that median TSF was significantly higher for vitamin D deficient (serum $25(\mathrm{OH}) \mathrm{D}<50 \mathrm{nmol} / \mathrm{L}$ ) group compared to a group with normal vitamin D status $(p<0.001)$. Likewise, the median TSF among older students was significantly higher than their younger counter parts $(p<0.001)$. Furthermore, females had significantly higher median TSF value than males $(p<0.001)$. It was also observed that the median TSF values differed significantly according to the following selected variables, respectively: students who had usual outdoor activities for less than $30 \mathrm{~min}$ both on school days and on weekend days had higher median TSF value than those who had usual outdoor activities for greater than $30 \mathrm{~min}$, students from mothers who have formal education had higher TSF value than students from mothers who have no formal education, and students from urban setting had higher TSF value than those from rural setting. However, there was no statistically significant difference between the median TSF values of respondents according to the occupation of both their fathers and mothers and also according to education status of their fathers. A Kruskal-Wallis test showed that median TSF values of respondents differ significantly among low, middle and high socioeconomic groups of the study subjects (Table 2).

Table 2. Differences in median TSF values of Ethiopian schoolchildren according to some study variables *.

\begin{tabular}{|c|c|c|c|}
\hline Variable $(n=174)$ & Frequency & Median TSF Value & $p$-Value \\
\hline \multicolumn{4}{|l|}{ Vitamin D status } \\
\hline Deficient & 73 & $16(5.2,31.2)$ & \multirow[t]{2}{*}{$p<0.001$} \\
\hline Normal & 101 & $10(5.6,29)$ & \\
\hline \multicolumn{4}{|l|}{ Sex } \\
\hline Male & 75 & $9(5.2,21.5)$ & \multirow[t]{2}{*}{$p<0.001$} \\
\hline Female & 99 & $16(5.6,31.2)$ & \\
\hline \multicolumn{4}{|l|}{ Age groups } \\
\hline $11-14$ & 77 & $10.3(5.2,24.7)$ & \multirow[t]{2}{*}{$p<0.001$} \\
\hline $15-18$ & 97 & $13.5(5.6,31.2)$ & \\
\hline \multicolumn{4}{|l|}{ Maternal education } \\
\hline Formal education & 35 & $12(6,29.8)$ & \multirow[t]{2}{*}{$p=0.008$} \\
\hline No formal education & 139 & $11(5.2,31.2)$ & \\
\hline \multicolumn{4}{|l|}{ Maternal occupation } \\
\hline Employed & 26 & $13.5(5.6,29.8)$ & \multirow[t]{2}{*}{$p=0.670$} \\
\hline Unemployed & 148 & $11.7(5.2,31.2)$ & \\
\hline \multicolumn{4}{|l|}{ Paternal education } \\
\hline Had formal education & 54 & $12(5.2,29.8)$ & \multirow[t]{2}{*}{$p=0.987$} \\
\hline Had no formal education & 120 & $11(5.6,31.2)$ & \\
\hline \multicolumn{4}{|l|}{ Paternal occupation } \\
\hline Employed & 50 & $12(5.6,29.8)$ & \multirow[t]{2}{*}{$p=0.736$} \\
\hline Unemployed & 124 & $11.6(5.2,31.2)$ & \\
\hline \multicolumn{4}{|c|}{ Daily outdoor activity on school days } \\
\hline$<30 \mathrm{~min}$ & 33 & $20(6,31)$ & \multirow[t]{2}{*}{$p<0.001$} \\
\hline$\geqslant 30 \mathrm{~min}$ & 141 & $11(5.2,31.2)$ & \\
\hline \multicolumn{4}{|c|}{ Daily outdoor activity on weekend days } \\
\hline$<30 \mathrm{~min}$ & 43 & $19(8,31.2)$ & \multirow[t]{2}{*}{$p<0.001$} \\
\hline$\geqslant 30 \mathrm{~min}$ & 141 & $10.3(5.2,28.8)$ & \\
\hline \multicolumn{4}{|l|}{ Residence } \\
\hline Urban & 89 & $14(6,31.2)$ & \multirow[t]{2}{*}{$p=0.048$} \\
\hline Rural & 85 & $10(5.2,28.8)$ & \\
\hline \multicolumn{4}{|l|}{ Socioeconomic status } \\
\hline Low & 60 & $9.7(5.2,28.8)$ & \multirow[t]{3}{*}{$p<0.001$} \\
\hline Middle & 53 & $13(5.6,31.2)$ & \\
\hline High & 61 & $13.2(6,29.8)$ & \\
\hline
\end{tabular}

* Values are in median (range); TSF $=$ triceps skin fold thickness. 
In bivariate logistic regression analyses, all variables except paternal education and paternal occupation had $p$-values of less than 0.25 and thus, entered into multivariable logistic regression model using backward elimination stepwise likelihood ratio method to identify independent predictors significantly associated with overweight and/or obesity. Accordingly, vitamin D deficiency, higher ager age group, female sex and residence of students, and their mothers' occupation of being employed and their households' high and middle socioeconomic status were independent predictors significantly associated with overweight and/or obesity after controlling for potential confounders using multivariable logistic regression model (Table 3).

Table 3. Predictors associated with overweight and/or obesity in multivariable logistic regression analysis for Ethiopian schoolchildren.

\begin{tabular}{|c|c|c|c|c|}
\hline \multirow{3}{*}{ Variables $(n=174)$} & \multicolumn{2}{|c|}{ Overweight and/or Obese } & \multirow{3}{*}{ COR $(95 \% \mathrm{CI})$} & \multirow{3}{*}{ AOR $(95 \% \mathrm{CI})$} \\
\hline & Yes & No & & \\
\hline & Number (\%) & Number (\%) & & \\
\hline \multicolumn{5}{|l|}{ Vitamin D status $^{1}$} \\
\hline Deficient & $14(77.8)$ & $59(37.8)$ & $5.75(1.81,18.31)$ & $4.59(1.11,18.91)$ \\
\hline Normal & $4(22.2)$ & $97(62.2)$ & Referent & Referent \\
\hline Serum 25(OH)D level ${ }^{1}$ & & & $0.945(0.91,0.98)$ & $0.946(0.89,0.99)^{\mu}$ \\
\hline \multicolumn{5}{|l|}{ Residence * } \\
\hline Urban & $15(83.3)$ & $74(47.4)$ & $5.54(1.54,19.90)$ & $5.29(1.45,19.36)$ \\
\hline Rural & $3(16.7)$ & $82(52.6)$ & Referent & Referent \\
\hline \multicolumn{5}{|l|}{ Gender } \\
\hline Male & $2(11.1)$ & $73(46.8)$ & Referent & Referent \\
\hline Female & $16(88.9)$ & $83(53.2)$ & $7.04(1.57,31.64)$ & $7.72(1.52,39.30)$ \\
\hline \multicolumn{5}{|l|}{ Age groups } \\
\hline $11-14$ & $3(16.7)$ & $74(47.4)$ & Referent & Referent \\
\hline $15-18$ & $15(83.3)$ & $82(52.6)$ & $4.51(1.26,16.21)$ & $6.66(1.46,30.29)$ \\
\hline \multicolumn{5}{|l|}{ Education (Father) } \\
\hline Formal education & $14(77.9)$ & $106(67.9)$ & Referent & Referent \\
\hline No formal education & $50(32.1)$ & $4(22.1)$ & $0.61(0.19,1.93)$ & $* *$ \\
\hline \multicolumn{5}{|l|}{ Education (Mother) } \\
\hline Formal education & $13(72.2)$ & $84(53.8)$ & Referent & Referent \\
\hline No formal education & $5(27.8)$ & $72(46.2)$ & $0.45(0.15,1.32)$ & $1.31(0.28,6.05)$ \\
\hline \multicolumn{5}{|l|}{ Occupation (Father) } \\
\hline Employed & $6(33.3)$ & $44(28.2)$ & & ** \\
\hline Unemployed & $12(66.7)$ & $112(71.8)$ & Referent & Referent \\
\hline \multicolumn{5}{|l|}{ Occupation (Mother) } \\
\hline Employed & $5(27.8)$ & $21(13.5)$ & $2.473(0.79,7.65)$ & $5.26(1.09,25.36)$ \\
\hline Unemployed & $13(72.2)$ & $135(86.5)$ & Referent & Referent \\
\hline \multicolumn{5}{|l|}{ Socioeconomic status } \\
\hline Low & $3(6.7)$ & $57(36.6)$ & Referent & Referent \\
\hline Middle & $8(44.4)$ & $45(28.8)$ & $0.41(0.10,1.65)$ & $17.89(1.12,87.18)$ \\
\hline High & $7(38.9)$ & $54(34.6)$ & $1.37(0.46,4.07)$ & $10.90(2.14,55.47)$ \\
\hline \multicolumn{5}{|l|}{$\begin{array}{l}\text { Daily outdoor activity } \\
\text { on school days }\end{array}$} \\
\hline$<30 \mathrm{~min}$ & $8(44.4)$ & $25(16.0)$ & $4.19(1.51,11.67)$ & $0.89(0.21,3.77)$ \\
\hline$\geqslant 30 \mathrm{~min}$ & $10(55.6)$ & $131(84.0)$ & Referent & Referent \\
\hline \multicolumn{5}{|l|}{$\begin{array}{l}\text { Daily outdoor activity } \\
\text { on weekend days }\end{array}$} \\
\hline$<30 \mathrm{~min}$ & $11(61.1)$ & $32(20.5)$ & $6.09(2.19,16.96)$ & $2.33(0.46,11.79)$ \\
\hline$\geqslant 30 \mathrm{~min}$ & $7(38.9)$ & $124(79.5)$ & Referent & Referent \\
\hline
\end{tabular}


Vitamin D deficiency was significantly associated with overweight and/or obesity in schoolchildren after controlling for possible confounding factors using multivariable logistic regression model. Vitamin D deficient students were about 4.6 times as likely to be overweight and/or obese compared to those students who had normal vitamin $\mathrm{D}$ status ( $\mathrm{AOR}=4.59(1.11,18.91)$ ). In addition, some socio-economic and demographic factors were found to have statistically significant association with overweight and/or obesity. Older children were about 6.7 times more likely to be overweight and/or obese compared to younger ones $(\mathrm{AOR}=6.66(1.46,30.29))$, while females were 7.72 times more likely to be overweight and/or obese than males (AOR $=7.72(1.52,39.30)$ ). Students whose mothers were employed had 5.26 times more odds of being overweight and/or obese compared to their counter parts $(\mathrm{AOR}=5.26(1.09,25.36))$. The respective odds of being overweight and / or obese among students from high and middle socioeconomic status households were 10.9 and 17.9 times higher compared to students from low socioeconomic status households $(\mathrm{AOR}=10.90(2.14,55.47)$ and AOR $=17.89(1.12,87.18)$, respectively). Similarly, students living in urban settings were 5.3 times more likely to be overweight and/or obese compared to those living in rural setting when controlled for age groups and vitamin D status of students and their households' socioeconomic status (AOR = 5.29 $(1.45,19.36))$.

\section{Discussion}

The present study demonstrates that vitamin D deficiency was significantly associated with overweight and/or obesity determined using TSF among schoolchildren in Ethiopia. There is evidence that skinfold thickness measurements are better predictors of body fat percentage than BMI in children and adolescents [36] as the use of BMI to identify overweight children at risk for metabolic disorders has limitations [37]. There is evidence from cell culture and animal model studies that adipose tissue has both the vitamin $\mathrm{D}$ receptor (VDR) and the ability to synthesize 1,25-dihydroxyvitamin $\mathrm{D}_{3}$, the bioactive vitamin D metabolite, and that vitamin D may regulate adipose tissue mass, differentiation and metabolism in ways that might contribute to overweight and/or obesity possibly by effects on lipogenesis and/or adipogenesis [38-43].

Although the exact biological mechanisms by which vitamin D may influence the various metabolic disorders are still under investigation, research findings from different epidemiological studies indicate that inadequate vitamin $\mathrm{D}$ has been found to be a predictor significantly associated with overweight and/or obesity and other components of metabolic syndrome including raised plasma glucose concentration and insulin resistance [44]. A number of studies have shown that vitamin D status is significantly associated with overweight and/obesity in children and adolescents. A cross-sectional study conducted on the nationally representative sample of Korean adolescents indicated that being vitamin D deficient $(25(\mathrm{OH}) \mathrm{D}$ level $<50 \mathrm{nmol} / \mathrm{L})$ appeared to be associated with higher risk for overweight or obesity, even after adjusting for confounders [45]. Moreover, Lee et al. [46] reported that serum 25(OH)D concentrations had significant inverse association with adiposity indices in preadolescent children in Korea. In this study, for a unit increase in serum $25(\mathrm{OH}) \mathrm{D}$ concentration waist circumference (WC), BMI and body fat mass (BFM) were reduced by $28 \%, 10 \%$ and $12 \%$, respectively; however, body fat percentage (BFP) and TSF showed only marginal boundary for the association. Furthermore, this study showed that the overall risk of overweight was reduced by $13 \%$ per unit increase of $25(\mathrm{OH}) \mathrm{D}$ even after adjusting for relevant confounding factors. The risk of obesity also decreased with a unit increase in the $25(\mathrm{OH}) \mathrm{D}$ level, but $p$-values for these associations showed borderline significance [46]. These findings support our data which showed that for a unit increase in serum $25(\mathrm{OH}) \mathrm{D}$ level, the risk of overweight and/or obesity is reduced by $5.6 \%$ when adjusting for confounders using multivariable logistic regression model suggesting a possible protective role of vitamin D against overweight and/or obesity in our study. Similarly, a cross-sectional study by Zhang et al. [47] among Chinese schoolchildren showed that the vitamin D deficiency group had significantly higher body weight, BMI, waist circumference and \% body fat (PBF), all of which are proxy indicators of overweight and/or obesity. Our study findings are in line with these findings 
demonstrating that vitamin D deficient subjects had significantly higher mean BMI and higher median TSF than their counterparts with normal vitamin D status.

In addition, a case control study undertaken on overweight/obese Caucasian children and adolescents and their controls of normal weight in the Rome area revealed that there were multivariable-adjusted significant associations between low serum 25(OH)D levels and obesity and other cardiometabolic risk factors [44].

Prospective epidemiological studies in human subjects also reported vitamin D deficiency is significantly associated with overweight and/or obesity. For instance, Gilbert-Diamond et al. [48] in their three-year prospective study among schoolchildren from Colombia concluded that low vitamin D status $(25(\mathrm{OH}) \mathrm{D}$ levels $<50 \mathrm{nmol} / \mathrm{L})$ was inversely associated with the development of adiposity. This study indicated that vitamin D deficient children had $0.1 \mathrm{~kg} / \mathrm{m}^{2}, 0.03$ and $0.8 \mathrm{~cm}$ significantly greater yearly change in BMI, subscapular-to-triceps skinfold thickness ratio and waist circumference, respectively, than did vitamin D sufficient children suggesting vitamin D deficiency is associated with adiposity. A similar findings were reported in follow-up study of younger children in Korea where those children with the lowest quartile of $25(\mathrm{OH}) \mathrm{D}$ levels had the highest serum triacylglycerol levels that might be due to higher adiposity [49]. Similarly, a longitudinal study on older Norwegians adult population revealed that low serum $25(\mathrm{OH}) \mathrm{D}$ levels $(<50 \mathrm{nmol} / \mathrm{L})$ were associated with a significantly increased risk for incident obesity during a follow-up period [50].

On the other hand, evidences show that overweight/obesity is associated with vitamin D deficiency. Indeed, we have previously reported that overweight/obese children were found to have lower serum 25(OH)D than non-overweight/obese children [25]. This might be due to either volumetric dilution of vitamin $D$ in the large fat mass or its increased uptake by adipose tissue in overweight/obese subjects [51-53]. In our study it was observed that students in high and middle socioeconomic groups were more likely to be overweight/obese. There is evidence that overweight/obesity in children is generally considered to have a positive association with socioeconomic status in developing countries [20]. Similarly, being in higher age group, urban residence and female sex were significantly associated with overweight/obesity. This might be due to reduced physical activities and increased sedentary life style behaviors with age and in urban students and in girls [54]. Furthermore, students whose mothers were employed had significantly increased risk of being overweight/obese. This might be explained by employed mothers could have inadequate time to supervise their children resulting in consumption of more unhealthy foods and less healthy foods of the children that could increase this risk [55]. The other possible reason for higher level of overweight/obesity among urban children could be due to their higher consumption of animal source foods that could be rich in fats as discussed in our previous study [25].

This study is the first one to look at the associations between vitamin D status and risk of overweight and/or obesity in Ethiopian schoolchildren. In addition, it might be among few studies that assessed overweight/obesity among school children using BMI-for-age and TSF-for-age. As childhood overweight/obesity is highly linked to adulthood obesity, the findings have wider implication on designing of prevention strategies for the emerging problem of adult chronic non-communicable diseases and associated morbidity and mortality in Ethiopia.

However, our study has some limitations. As a cross-sectional study, the associations it demonstrated do not imply a causal relationship between serum 25(OH)D concentrations and risk of overweight and/or obesity in our study subjects. In addition, the study may be confounded by a lack of data on some relevant variables such as information on total energy intake, more detailed physical activity levels, and dietary vitamin D intake such as egg yolk, fish and fish liver oil, meat and yeast fermented cereal based foods that could be available and accessible for consumption by the study subjects. 


\section{Conclusions}

In conclusion, vitamin D deficiency was found to be an independent predictor significantly associated with overweight and/or obesity among Ethiopian schoolchildren. The results imply the need for behavior change communication on the importance of exposure to sunlight to produce adequate vitamin $\mathrm{D}$ in Ethiopian schoolchildren to curb this emerging health problem of overweight/obesity and its associated long term health consequences following economic growth and globalization in Ethiopia. As the present study only highlighted the association between vitamin $\mathrm{D}$ deficiency and overweight/obesity in our study subjects, prospective studies and randomized controlled trials are required to establish causality.

Acknowledgments: Financial Support from College of Pharmacy and Nutrition, University of Saskatchewan.

Author Contributions: T.W., S.W. and T.B. designed research; T.W. conducted research; T.W., T.B. analyzed data; T.W. wrote the paper. S.W. had primary responsibility for final content. All authors read and approved the final manuscript.

Conflicts of Interest: Authors declare no conflict of interest. The funding sponsors had no role in the design of the study; in collection, analyses, or interpretation of data; in the writing of the manuscript, and in the decision to publish the results.

\section{References}

1. Jiang, X.X.; Hardy, L.L.; Baur, L.A.; Ding, D.; Wang, L.; Shi, H.J. High prevalence of overweight and obesity among inner city Chinese children in Shanghai, 2011. Ann. Hum. Biol. 2014, 41, 469-472. [CrossRef] [PubMed]

2. Campbell, T.; Campbell, A. Emerging Disease Burdens and the Poor in Cities of the Developing World. J. Urban Health 2007, 84, i54-i64. [CrossRef] [PubMed]

3. Rokholm, B.; Baker, J.L.; Sorensen, T.I. The levelling off of the obesity epidemic since the year 1999-A review of evidence and perspectives. Obes. Rev. 2010, 11, 835-846. [CrossRef] [PubMed]

4. Olds, T.; Maher, C.; Shi, Z.M.; Peneau, S.; Lioret, S.; Castetbon, K.; Bellisle; de Wilde, J.; Hohepa, M.; Maddison, R.; et al. Evidence that the prevalence of childhood overweight is plateauing: Data from nine countries. Int. J. Pediatr. Obes. 2011, 6, 342-360. [CrossRef] [PubMed]

5. Wabitsch, M.; Moss, A.; Kromeyer-Hauschild, K. Unexpected plateauing of childhood obesity rates in developed countries. BMC Med. 2014, 12. [CrossRef] [PubMed]

6. Gupta, N.; Goel, K.; Shah, P.; Misra, A. Childhood obesity in developing countries: Epidemiology, determinants, and prevention. Endocr. Rev. 2012, 33, 48-70. [CrossRef] [PubMed]

7. Rohilla, R.; Rajput, M.; Rohilla, J.; Malik, M.; Garg, D.; Verma, M. Prevalence and Correlates of Overweight/Obesity among Adolescents in an Urban City of North India. J. Fam. Med. Prim. Care 2014, 3, 404-408. [CrossRef] [PubMed]

8. Guo, X.F.; Zheng, L.Q.; Li, Y.; Zhang, X.Y.; Yu, S.S.; Yang, H.M.; Zhang, X.G.; Sun, Z.Q.; Sun, Y.X. Prevalence and risk factors of being overweight or obese among children and adolescents in northeast China. Pediatr. Res. 2013, 74, 443-449. [CrossRef] [PubMed]

9. Ng, M.; Fleming, T.; Robinson, M.; Thomson, B.; Graetz, N.; Margono, C.; Mullany, E.C.; Biryukov, S.; Abbafati, C.; Abera, S.F.; et al. Global, regional, and national prevalence of overweight and obesity in children and adults during 1980-2013: A systematic analysis for the Global Burden of Disease Study 2013. Lancet 2014, 384, 766-781. [CrossRef]

10. Al-Ghamdi, S.H. The association between watching television and obesity in children of school-age in Saudi Arabia. J. Fam. Community Med. 2013, 20, 83-89. [CrossRef] [PubMed]

11. Mistry, S.K.; Puthussery, S. Risk factors of overweight and obesity in childhood and adolescence in South Asian countries: A systematic review of the evidence. Public Health 2015, 129, 200-209. [CrossRef] [PubMed]

12. Belachew, T. Are we ready for the rising silent epidemic of metabolic syndrome and chronic non-communicable disease in Ethiopia? Ethiop. J. Health Sci. 2014, 24, 1-2. [CrossRef]

13. Onywera, V.O. Childhood obesity and physical inactivity threat in Africa: Strategies for a healthy future. Glob. Health Promot. 2010, 17, 45-46. [CrossRef] [PubMed] 
14. Navti, L.K.; Ferrari, U.; Tange, E.; Pozza, S.B.-D.; Parhofer, K.G. Contribution of socioeconomic status, stature and birth weight to obesity in Sub-Saharan Africa: Cross-sectional data from primary school-age children in Cameroon. BMC Public Health 2014. [CrossRef] [PubMed]

15. Kimani-Murage, E.W.; Kahn, K.; Pettifor, J.M.; Tollman, S.M.; Dunger, D.B.; Gómez-Olivé, X.F.; Norris, S.A. The prevalence of stunting, overweight and obesity, and metabolic disease risk in rural South African children. BMC Public Health 2010. [CrossRef] [PubMed]

16. Rosengren, A.; Teo, K.; Rangarajan, S.; Kabali, C.; Khumalo, I.; Kutty, V.R.; Gupta, R.; Yusuf, R.; Iqbal, R.; Ismail, N.; et al. Psychosocial factors and obesity in 17 high-, middle- and low-income countries: The prospective urban rural epidemiologic study. Int. J. Obes. 2015, 39, 1217-1223. [CrossRef] [PubMed]

17. Peltzer, K.; Pengpid, S. Overweight and Obesity and Associated Factors among School-Aged Adolescents in Ghana and Uganda. Int. J. Environ. Res. Public Health 2011, 8, 3859-3870. [CrossRef] [PubMed]

18. Tebekaw, Y.; Teller, C.; Colón-Ramos, U. The burden of underweight and overweight among women in Addis Ababa, Ethiopia. BMC Public Health 2014, 14, 1126. [CrossRef] [PubMed]

19. Teshome, T.; Singh, P.; Moges, D. Prevalence and Associated Factors of Overweight and Obesity among High School Adolescents in Urban Communities of Hawassa, Southern Ethiopia. Curr. Res. Nutr. Food Sci. J. 2013, 1, 23-36. [CrossRef]

20. Fezeu, L.; Minkoulou, E.; Balkau, B.; Kengne, A.P.; Awah, P.; Unwin, N.; Alberti, G.K.M.M.; Mbanya, J.C. Association between socioeconomic status and adiposity in urban Cameroon. Int. J. Epidemiol. 2005, 35, 105-111. [CrossRef] [PubMed]

21. Rafraf, M.; Hasanabad, S.K.; Jafarabadi, M.A. Vitamin D status and its relationship with metabolic syndrome risk factors among adolescent girls in Boukan, Iran. Public Health Nutr. 2013, 17, 803-809. [CrossRef] [PubMed]

22. Delvin, E.E.; Lambert, M.; Levy, E.; O’Loughlin, J.; Mark, S.; Gray-Donald, K.; Paradis, G. Vitamin D Status Is Modestly Associated with Glycemia and Indicators of Lipid Metabolism in French-Canadian Children and Adolescents. J. Nutr. 2010, 140, 987-991. [CrossRef]

23. Mitri, J.; Nelson, J.; Ruthazer, R.; Garganta, C.; Nathan, D.M.; Hu, F.B.; Dawson-Hughes, B.; Pittas, A.G. Plasma 25-hydroxyvitamin D and risk of metabolic syndrome: An ancillary analysis in the Diabetes Prevention Program. Eur. J. Clin. Nutr. 2014, 68, 376-383. [CrossRef] [PubMed]

24. Reis, J.P.; von Mühlen, D.; Miller, E.R.; Michos, E.D.; Appel, L.J. Vitamin D Status and Cardiometabolic Risk Factors in the US Adolescent Population. Pediatrics 2009, 124, e371-e379. [CrossRef] [PubMed]

25. Wakayo, T.; Belachew, T.; Vatanparast, H.; Whiting, S.J. Vitamin D Deficiency and its Predictors in a Country with Thirteen Months of Sunshine: The Case of School Children in Central Ethiopia. PLoS ONE 2015, 10, e0120963.

26. Fogelman, Y.; Rakover, Y.; Luboshitzky, R. High prevalence of vitamin D deficiency among Ethiopian women immigrants to Israel: Exacerbation during pregnancy and lactation. Isr. J. Med. Sci. 1995, 31, 221-224. [PubMed]

27. Egziabher, T.G.; Stoecker, B.J. Vitamin D insufficiency in a sunshine-sufficient area: Southern Ethiopia. Food Nutr. Bull. 2013, 34, 429-433.

28. Feleke, Y.; Abdulkadir, J.; Mshana, R.; Mekbib, T.A.; Brunvand, L.; Berg, J.P.; Falch, J.A. Low levels of serum calcidiol in an African population compared to a North European population. Eur. J. Endocrinol. 1999, 141, 358-360. [CrossRef] [PubMed]

29. Gebreyohannes, Y.; Shiferaw, S.; Demtsu, B.; Bugssa, G. Nutritional status of adolescents in selected government and private secondary schools of Addis Ababa, Ethiopia. Int. J. Food Sci. Nutr. 2014, 3, 504-514. [CrossRef]

30. Alemu, E.; Atnafu, A.; Yitayal, M.; Yimam, K. Prevalence of Overweight and/or Obesity and Associated Factors among High School Adolescents in Arada Sub city, Addis Ababa, Ethiopia. J. Nutr. Food Sci. 2014. [CrossRef]

31. Gebregergs, G.B.; Yesuf, M.E.; Beyen, T.K. Overweight and Obesity, and Associated Factors among High School Students in Gondar Town, North West Ethiopia. J. Obes. Weight Loss Ther. 2013. [CrossRef]

32. Gebremariam, H.; Seid, O.; Assefa, H. Assessment of nutritional status and associated factors among school going adolescents of Mekelle City, Northern Ethiopia. Int. J. Food Sci. Nutr. 2015, 4, 118-124. [CrossRef]

33. Vatanparast, H.; Nisbet, C.; Gushulak, B. Vitamin D insufficiency and bone mineral status in a population of newcomer children in Canada. Nutrients 2013, 5, 1561-1572. [CrossRef] [PubMed] 
34. Holick, M.F.; Binkley, N.C.; Bischoff-Ferrari, H.A.; Gordon, C.M.; Hanley, D.A.; Heaney, R.P.; Murad, M.H.; Weaver, C.M. Evaluation, Treatment, and Prevention of Vitamin D Deficiency: An Endocrine Society Clinical Practice Guideline. J. Clin. Endocrinol. Metab. 2011, 96, 1911-1930. [CrossRef] [PubMed]

35. WHO. Physical Status: The Use and Interpretation of Anthropometry; Technical Report Series No. 854; WHO: Geneva, Switzerland, 1995.

36. Sarrõ Âa, A.; Âa-Llop, L.A.G.; Moreno, L.A.; Fleta, J.; Ân, M.P.M.; Bueno, M. Skinfold thickness measurements are better predictors of body fat percentage than body mass index in male Spanish children and adolescents. Eur. J. Clin. Nutr. 1998, 52, 573-576. [CrossRef]

37. Aeberli, I.; Gut-Knabenhans, M.; Kusche-Ammann, R.S.; Molinari, L.; Zimmermann, M.B. A composite score combining waist circumference and body mass index more accurately predicts body fat percentage in 6- to 13-year-old children. Eur. J. Nutr. 2013, 52, 247-253. [CrossRef] [PubMed]

38. Earthman, C.; Beckman, L.; Masodkar, K.; Sibley, S. The link between obesity and low circulating 25-hydroxyvitamin D concentrations: Considerations and implications. Int. J. Obes. 2012, 36, 387-396. [CrossRef] [PubMed]

39. Wood, R.J. Vitamin D and adipogenesis: New molecular insights. Nutr. Rev. 2008, 66, 40-46. [CrossRef] [PubMed]

40. Mutt, S.J.; Hyppönen, E.; Saarnio, J.; Järvelin, M.-R.; Herzig, K.-H. Vitamin D and adipose tissue-More than storage. Front. Physiol. 2014. [CrossRef] [PubMed]

41. Kong, J.; Li, Y.C. Molecular mechanism of 1,25-dihydroxyvitamin $\mathrm{D}_{3}$ inhibition of adipogenesis in 3T3-L1 cells. Am. J. Physiol. Endocrinol. Metab. 2006, 290, E916-E924. [CrossRef] [PubMed]

42. Ricciardi, C.J.; Bae, J.; Esposito, D.; Komarnytsky, S.; Hu, P.; Chen, J.G.; Zhao, L. 1,25-Dihydroxyvitamin $\mathrm{D}_{3} /$ vitamin $\mathrm{D}$ receptor suppresses brown adipocyte differentiation and mitochondrial respiration. Eur. J. Nutr. 2015, 54, 1001-1012. [CrossRef] [PubMed]

43. Ryan, K.J.P.; Daniel, Z.C.T.R.; Craggs, L.J.L.; Brameld, T.P.M. Dose-dependent effects of vitamin D on transdifferentiation of skeletal muscle cells to adipose cells. J. Endocrinol. 2013, 217, 45-58. [CrossRef] [PubMed]

44. Pacifico, L.; Anania, C.; Osborn, J.F.; Ferraro, F.; Bonci, E.; Olivero, E.; Chiesa, C. Low 25(OH)D $\mathrm{D}_{3}$ levels are associated with total adiposity, metabolic syndrome, and hypertension in Caucasian children and adolescents. Eur. J. Endocrinol. 2011, 165, 603-611. [CrossRef] [PubMed]

45. Nam, G.E.; Kim, D.H.; Cho, K.H.; Park, Y.G.; Han, K.D.; Kim, S.M.; Lee, S.H.; Ko, B.J.; Kim, M.J. 25-Hydroxyvitamin D insufficiency is associated with cardiometabolic risk in Korean adolescents: The 2008-2009 Korea National Health and Nutrition Examination Survey (KNHANES). Public Health Nutr. 2012, 17, 186-194. [CrossRef] [PubMed]

46. Lee, H.A.; Kim, Y.J.; Lee, H.; Gwak, H.S.; Park, E.A.; Cho, S.J.; Oh, S.Y.; Ha, E.H.; Kim, H.S.; Park, H. Association of vitamin D concentrations with adiposity indices among preadolescent children in Korea. J. Pediatr. Endocrinol. Metab. 2013, 26, 849-854. [CrossRef] [PubMed]

47. Zhang, H.Q.; Teng, J.H.; Li, Y.; Li, X.X.; He, Y.H.; He, X.; Sun, C.H. Vitamin D status and its association with adiposity and oxidative stress in schoolchildren. Nutrition 2014, 30, 1040-1044. [CrossRef] [PubMed]

48. Gilbert-Diamond, D.; Baylin, A.; Mora-Plazas, M.; Marin, C.; Arsenault, J.E.; Hughes, M.D.; Willett, W.C.; Villamor, E. Vitamin D deficiency and anthropometric indicators of adiposity in school-age children: A prospective study. Am. J. Clin. Nutr. 2010, 92, 1446-1151. [CrossRef] [PubMed]

49. Kwon, J.H.; Lee, S.E.; Lee, H.A.; Kim, Y.J.; Lee, H.Y.; Gwak, H.S.; Park, E.A.; Cho, S.J.; Oh, S.Y.; Ha, E.H.; et al . Relationship of serum 25-Hydroxyvitamin D (25[OH]D) levels and components of metabolic syndrome in prepubertal children. Nutrition 2015, 31, 1324-1327. [CrossRef] [PubMed]

50. Mai, X.-M.; Chen, Y.; Carlos, A.; Camargo, J.; Langhammer, A. Cross-sectional and prospective cohort study of serum 25-hydroxyvitamin D level and obesity in adults: The HUNT study. Am. J. Epidemiol. 2012, 175, 1029-1036. [CrossRef] [PubMed]

51. Drincic, A.T.; Armas, L.A.G.; Diest, E.E.V.; Heaney, R.P. Volumetric dilution, rather than sequestration best explains the low vitamin D status of obesity. Obesity 2012, 20, 1444-1448. [CrossRef] [PubMed]

52. Abboud, M.; Gordon-Thomsona, C.; Hoya, A.J.; Balaban, S.; Rybchyn, M.S.; Cole, L.; Su, Y.Y.; Brennan-Speranza, T.C.; Fraser, D.R.; Mason, R.S. Uptake of 25-hydroxyvitamin D by muscle and fat cells. J. Steroid. Biochem. Mol. Biol. 2014, 144, 232-236. [CrossRef] [PubMed] 
53. Blum, M.; Dolnikowski, G.; Seyoum, E.; Harris, S.S.; Booth, S.L.; Peterson, J.; Saltzman, E.; Dawson-Hughes, B. Vitamin $\mathrm{D}_{3}$ in fat tissue. Endocrine 2008, 33, 90-94. [CrossRef]

54. Onywera, V.O.; Heroux, M.; Ulloa, E.; Jauregui, A.K.; Taylor, J.L.; Janssen, I.; Tremblay, M.S. Adiposity and physical activity among children in countries at different stages of the physical activity transition: Canada, Mexico and Kenya. Afr. J. Phys. Health Educ. Recreat. Dance 2013, 19, 132-142.

55. Datar, A.; Nicosia, M.; Shier, V. Maternal Work and Children's Diet, Activity, and Obesity. Soc. Sci. Med. 2014, 107, 196-204. [CrossRef] [PubMed]

(C) 2016 by the authors; licensee MDPI, Basel, Switzerland. This article is an open access article distributed under the terms and conditions of the Creative Commons by Attribution (CC-BY) license (http://creativecommons.org/licenses/by/4.0/). 